\title{
L'encaix de la narrativa sense ficció de Víctor Labrado en el paradigma de la novel la històrica valenciana
}

\section{The fitting of Víctor Labrado's nonfiction narrative in the paradigm of the Valencian historical novel}

\author{
DARI ESCANDELL \\ dari.escandell@ua.es
}

Universitat d'Alacant

\begin{abstract}
Resum: L'escriptor valencià Víctor Labrado (Sueca, 1956) s'ha erigit com un dels grans referents contemporanis en el camp de la novel la de no-ficció en català, subgènere narratiu que conjumina la intenció metanovel lesca amb fidedignes discursos testimonials. Ara bé, ¿les obres cabdals de Labrado -peculiars, idiosincràtiques i gens usuals- poden ser considerades també, sense subterfugis ni matisos, novel la històrica? A grans trets: trames guerracivilistes empeltades d'entrevistes, dosis generoses de periodisme documental i absència gairebé absoluta de ficció. La tècnica i l'estil propi no suposen, però, cap impediment perquè molts llibres seus siguen alhora novel la històrica, si fem cas dels topoi convinguts per la crítica especialitzada. No debades, aquests exemplars esdevenen, al capdavall, testimoni viu d'un temps passat; vivències i peripècies de gent anònima que rescaten de l'oblit, des de la particularitat més universal, la realitat valenciana d'un segle passat vilment estigmatitzat pel conflicte civil de l'any 1936 i la dictadura consegüent. ¿N'hi ha prou amb això, però, perquè aquesta etiqueta o clixé siga atribuible també a la resta de la seua obra i trajectòria? El present article analitza a nivell tècnic, argumental i conceptual els llibres essencials de Labrado per tal de determinar quina part de la seua novel lística sense ficció pot o no considerar-se al seu torn novel la històrica.
\end{abstract}

Paraules clau: Víctor Labrado, novel la sense ficció, novel la històrica, literatura catalana, valencià.

Abstract: The Valencian writer Víctor Labrado (Sueca, 1956) has emerged as one of the great contemporary references in the field of the non-fiction novel in Catalan, a narrative subgenre that combines the fictional intention with real testimonial speeches. However, can Labrado's capital books -peculiar, idiosyncratic and unusual- be considered also, without subterfuges or hints, historical novels? Broadly speaking: are his Spanish civil war plots grafted with interviews, generous doses of documentary journalism and almost absolute absence of fiction, historical novels? Its techniques and style are no impediment to say so, if we pay attention to the topoi agreed by the specialized critic. In fact, these novels become, in short, a living testimony of our past time: they rescue from oblivion the experiences and adventures of anonymous people, from the most universal particularity, and the Valencian reality of a past century stigmatized by the civil conflict of 1936 and the consequent dictatorship. Is that enough, however, to attribute this label to the rest of his literary works? This paper analyses the techniques, the plots and the concepts of Labrado's essential books to determine what part of his nonfiction novels may or may not be considered historical.

Keywords: Víctor Labrado, nonfiction novel, historical novel, Catalan literature, Valencian. 
Dari Escandell. L’encaix de la narrativa sense ficció de Víctor Labrado en el paradigma de la novel la històrica valenciana

Jo escric realisme. Hui en dia això no té prestigi. Forma part de la segona fila de la narrativa. A mi m'és exactament igual: jo faig el que m’interessa i el que m’agrada. Però sí que puc dir que el realisme està plenament justificat.

Víctor Labrado, Plaerdemavida, À Punt Mèdia, 17/11/2018

\section{Introducció}

El periple -vast, reeixit, excepcional- de Víctor Gómez Labrado (Sueca, 1956) com a assagista, biògraf de prohoms i etnopoetòleg, no desllueix tanmateix la seua trajectòria com a novel lista, una vessant aquesta altra no del tot paral lela a les anteriors $i$ tal volta un pèl tardana, però ben probablement per això mateix, ferma, genuïna, idiosincràtica i cada vegada més i millor reconeguda. Labrado és, de fet, un dels escriptors valencians actuals més prolífics en premis i nombre de lectors, si més no de l'anomenada novel la testimonial, altrament coneguda com a literatura de no-ficció. Bona part dels seus llibres són precisament cròniques narratives en què l'escriptor suecà combina un discurs metaficcional provinent d'estudis historiogràfics i-sobretot- d'entrevistes a testimonis reals, amb dosis puntuals de ficció novel lesca, si bé l'empremta d'aquesta altra fórmula literària resulta en termes generals certament esquifida i efímera dins de l'univers creatiu global de Labrado. No obstant això, cada una de novel les sense ficció d'aquest autor presenta pecualiaritats i particularitats tècniques, discursives, temàtiques i argumentals, fins al punt que l'opinió de la crítica especialitzada pot dissentir entre si a l'hora de catalogar segons llibres -sense objecció i unànimement- dins del ventall gairebé infinit del que hom considera novel la històrica. Gustau Muñoz (2014) subratlla en aquest sentit que el País Valencià està assistint aquests darrers anys a

\footnotetext{
la gran florida de la novel la històrica. (...) Per la raó que siga, històries farcides de moriscos, jueus conversos o no, trabucaires, bandolers, agermanats, monges i predicadors, inquisidors, cavallers, poetes de cort i les grans figures històriques, més o menys familiars per als lectors, omplen les pàgines d'una bona part de la narrativa valenciana més publicada i reconeguda (Muñoz 2014).
}

Sovint, però, molts escriptors valencians no circumscriuen aquests llibres a «personatges sobresortints i més coneguts, sinó que exploren els ambients més anònims, fent de vegades exercicis meritoris d'història social, dels subalterns, dels vençuts, d'història des de baix» (Muñoz 2014). Aquesta equació de voler fer -literàriament- història social des de baix, donant-li veu als vençuts, és de fet la premissa neuràlgica de Labrado en confegir el cicle de novel les arrecerades al voltant del fil temàtic del conflicte bèl lic espanyol de l'any 1936 i la repressió civil subsegüent: La guerra de quatre (2002), Quan anàvem a l'estraperlo (2004) o No mataràs (2015) esdevenen testimoni viu d'un temps passat -pretenen ser-ho, al cap i a la fi-; vivències i peripècies de gent anònima que rescaten de 
l'oblit, des de la particularitat més universal, la realitat social de la primera meitat d'un segle passat vilment estigmatitzat per la Guerra Civil i la dictadura -crua, venjativa, gairebé sempiterna per a gran part de tota una generació de valencianes i valencians- que hi seguirà. Encara que les trames argumentals respectives d'aquestes novel les pràcticament desproveïdes de ficció estan empeltades, en sengles casos, pel relat esfereïdor dels múltiples testimonis (directes i indirectes) entrevistats i per una meticulosa faena de periodisme documental, el fet cert és que els elements temàtics, tècnics i conceptuals d'aquesta sèrie de llibres de natura guerracivilista de Labrado encaixen perfectament -sense estridències- dins de l'etiqueta genèrica de novel la històrica, si ens atenem als ítems referencials estipulats per la crítica especialitzada. Al llarg d'aquest article en parlarem a bastament. ¿Tal catalogació, però, quedaria reduïda exclusivament a aquelles obres en què Labrado emplaça trama, personatges i argument entre l'imminent esclat de la Guerra Civil espanyola i els primers anys del règim dictatorial consegüent? ¿O potser també podria fer-se extensible -igualment, anàlogament- a unes altres cròniques literàries seues sobre episodis històrics menys virals, no tan llunyans en el temps i molt més inadvertits (per desconeguts) pel gruix de la societat valenciana? Ens referim als fets arreplegats en La mestra (1995) o Veus, la mar (2018). Aquest estudi provarà de posar-hi fil a l'agulla.

\title{
2. Novel 1a històrica sense ficció
}

Potser fora agosarat parlar de trilogia en referir-nos a Quan anàvem a l'estraperlo, La guerra de quatre i No mataràs atesa la idiosincràsia pròpia de cada llibre quant a protagonistes, estil o trama argumental. Per contra, totes tres publicacions transcorren cronològicament al llarg de l'altre gran període temporal de la novel la històrica valenciana, contrapunt respecte de la plenitud medieval i la ja no tan esplendorosa edat moderna (Salvador 1986):

\begin{abstract}
Un altre període històric, ja més acostat en el temps, que excita la pulsió creativa de molts escriptors valencians, $i$ que ha estat rerefons de nombroses novel les, és l'època de la guerra civil, que de vegades inclou la República, en clau d'esperança desfeta, de gran entusiasme popular ensorrat després enmig de la repressió, l’oblit, la fam i la misèria de la postguerra. (...) Algú hauria de fer un recompte aprofundit i precís, quantificat, d'autors, intencions, obres $\mathrm{i}$ arguments. La nòmina completa (...) ens deixaria parats, tan àmplia com seria (Muñoz 2014).
\end{abstract}

Òbviament, l'element temporani esdevé per si mateix insuficient a l'hora d'emetre un veredicte favorable -sense parangó ni discussió, unànime- respecte a la inclusió d'aquests llibres de Labrado en el terreny inequívoc de la novel la històrica. Tanmateix, un estudi crític de Vicent Simbor, lúcid i clarivident, hi aplana prou el pla. El fet cert és que en termes generals,

la novel la històrica ha sigut entesa com un producte bastard o híbrid (...) Ens trobem, doncs, amb l'aparent impossibilitat de veure barrejades en la mateixa obra la ficció, pròpia de la 


\title{
Dari Escandell. L'encaix de la narrativa sense ficció de Víctor Labrado en el paradigma de la novel la històrica valenciana
}

\begin{abstract}
Literatura, i la referencialitat i objectivitat, pròpies de la Història. O si ho preferim dir així: la difícil unió entre la Bellesa i la Veritat. És clar que un dels topoi majors, la regla essencial, és la reivindicació de la novel la històrica capaç de realitzar amb èxit la juntura entre la veritat i la invenció (...) conjunció harmoniosa dels contraris. (...) aquesta unió inestable i difícil entre llibertat creativa i deute referencial s'ha vist des de l'origen com el tret essencial de la novel la històrica (Simbor 1997: 107-109).
\end{abstract}

\subsection{El cicle guerracivilista de Labrado}

Tot el món coincidirà a reconéixer, en clau sociològica, que la novel la històrica valenciana

\begin{abstract}
ha fet i fa una contribució molt destacada a la formació de la consciència col lectiva, a la fixació de referents nacionals en l'imaginari d'un seguit de generacions, a l'assentament de la visió d'una història pròpia (...) una història que, certament, hom va voler esborrar i fer caure en l'oblit. (...) Per això l'aportació de la novel la històrica, més enllà de la seua vàlua literària estricta (que és una altra qüestió), és tan significativa (Muñoz 2014).
\end{abstract}

La voluntat última de l'escriptor suecà és en efecte aquesta, sense desmeréixer ni renunciar per això a la qualitat estètica del producte. Tècnicament, «molts dels llibres que Víctor Labrado ha escrit entrarien en una mena de gènere que anomenaríem documentalista. L'autor parteix d'informació arreplegada, viscuda, sentida o generada mitjançant entrevistes i la transforma en matèria narrativa» (Escolano 2013: 253). Teresa Guillaumes (2004: 169) estableix a tal efecte dues tipologies diferenciades de novel la històrica: les que se cenyeixen temàticament als corrents literaris del moment $i$ aquelles altres que han esdevingut creacions si fa no fa alienes a les modes; és de fet en aquest segon esclavó on situaríem les novel les de Labrado.

La condició d'outsider de les lletres catalanes contemporànies, però, respon més aïna al fet que en són ben pocs, en el marc actual del panorama literari nostrat, els qui practiquen, a part d'ell, aquest subgènere específic de novel la històrica mancat de ficció. Parlant precisament d'un llibre seu, Àlex Milian (2019) addueix que

Els límits entre la novel la de ficció i la de no-ficció es van trencar clarament durant la segona meitat del segle XX gràcies als esforços d'un escriptor imponent, Truman Capote, i la pressió d'una colla de periodistes esbojarrats -reunits al voltant de la revista Rolling Stone i liderats per Tom Wolfe. Entre més característiques, aquesta novel la de no-ficció nascuda del periodisme es va forjar amb investigació pròpia de reporter, descripcions acurades dels escenaris reals dels successos, entrevistes amb els protagonistes i reproducció de la seva parla. (...) A les novel les de no-ficció ja clàssiques -nascudes del periodisme- s'hi van anar afegint els arguments i les tècniques de la història oral i l'antropologia fins a arribar a l'extrem de la premi Nobel Svetlana Aleksiévitx, que encadena temàticament centenars de testimonis en obres monumentals com La pregària de Txernòbil o Temps de segona mà. La fi de l'home roig (Milian 2019). 
Aquests referents universals inspiren de ben segur la tècnica narrativa de Labrado, sobretot en la seua darrera -per ara- novel la guerracivilista: No mataràs (2015), guardonada amb el XX Premi Enric Valor de Novel la de la Diputació d'Alacant. El rerefons de l'obra irradia també certa influència de Paul Preston (2010), confirmada per l'autor mateix en una entrevista radiofònica recent. ${ }^{1} \mathrm{La}$ transcripció literària dels successos i fets històrics, reconstruïda en essència a partir d'entrevistes a gent de l'entorn del protagonista, però, respon a uns altres patrons tècnics i destreses en les dues novel les escrites i publicades vora una dècada abans.

Per un cantó, la història que amera Quan anàvem a l'estraperlo (2004) és un testimoni extraordinari de la lluita per sobreviure en aquell temps i context sobrevingudament capritxós. Ricard Peris, editor d'Andana Editorial -qui conscient del valor de la peça, n'ha adquirit recentment els drets comercials a fi de reeditar-la de nou-, la considera una narració d'estil despullat, directe i vibrant a mitjan camí entre la novel la d'aventures i la crònica, que reconstrueix la memòria d'una període duríssim, comprés entre el final de la II República i la immediata postguerra, quan a la misèria i a la fam calia sumar la repressió franquista (Peris 2017). El llibre testimonia aventures i peripècies -algunes de les quals, veritables odissees- mitjançant personatges reals amb noms i cognoms. Individus alguns hui en dia encara vius que escenifiquen la picaresca d'aquella generació de valencians de condició pobra i humil -l'anomenada classe subalterna- que aprengué com ningú a burlar l'autoritat per poder guanyar-se les garrofes. En la forçosa clandestinitat, Vicentet (Vicent Just Millet), el jove protagonista d'aquesta novel la, recorre el bocí de país entre València i Alacant carregat d'arròs, blat, oli o sardines per tal de bescanviar aquests productes per uns altres aliments difícils d'aconseguir enllà del mercat negre. I és que com bé rebla Labrado, «Fou una època de racionament dels aliments bàsics i de restriccions de tota mena. Anar a l'estraperlo era una de les poques sortides dignes» (Labrado 2017). L'exercici reeixit de transcripció i recreació, per part de l'autor, del testimoni lúcid -amb pèls i senyals, impecable en detalls al cap de vora setanta anys- del cèlebre veí de la Font d'En Carròs Vicent Just Millet, palesa la complexitat que comporta la translació a crònica novel lada d'uns fets reals relatats de primera mà: el difícil impàs del discurs literal al realisme literari.

Per un altre cantó, La guerra de quatre (Bromera, 2002) és més aviat la reconstrucció fidel, gairebé periodística, a partir de la documentació disponible i del testimoni dels supervivents, d'uns fets protagonitzats per un grup urbà de resistència armada que, d'amagat pel rodal de València, finançava amb atracaments les activitats de l'oposició clandestina maqui:

La guerra de quatre no és una novel la. Des de les primeres pàgines se'ns adverteix que es
tracta de la crònica d'uns fets que van tenir lloc a les comarques centrals del País Valencià.
La reconstrucció dels esdeveniments es fa mitjançant els documents que n'han restat i el
testimoni oral de les persones supervivents que han volgut col laborar-hi. Algunes han permés
la publicació del seu nom, unes altres no. Tanmateix, la recreació dramàtica d'ambients i de
personatges és tan perfecta que sovint oblidem que no és una ficció. Conta aquesta crònica,
doncs, l'organització d'un grup de maquis urbà a Benetússer. (...) A poc a poc, el narradorens

1 https://apuntmedia.es/va/a-la-carta/programes/escoltat-en-la-radio/la-travessa/19-05-2019-la-travessa 


\begin{abstract}
va desvelant la formació del grup i les principals accions (robatoris i atemptats). Per tal d'entendre els protagonistes i el perquè d'alguns actes, abandonem el present del relat (1946) i observem els antecedents dels personatges (1935-1939). Sols així podrem comprendre, astorats, les mesquineses personals que s'amaguen darrere molts fets de guerra capritxosos i les repercussions, anys després, sobre les persones. (...) Això a banda, constatem en la narració d'aquests fets reals la brutalitat a les comissaries i a les presons. Assistim a interrogatoris rutinaris amb pallisses i tortures planificades. Llegim confessions fictícies per tal d'evitar colps. Reconstruïm casos de detenció, pallissa i empresonament per ser nóvia d'una persona buscada per la llei. Coneixem processos en què el jutge pressiona els inculpats per alterar-ne les declaracions. I assistim, en fi, a judicis i execucions militars (Beltran 2009).
\end{abstract}

En aquestes dues primeres novel les es parla ja -si bé de passada; com l'espectre d'algú que hi pul lula per l'imaginari popular- de Pepe el Carinyo, personatge excepcional que Víctor Labrado recuperarà més avant fins al punt de convertir-lo en el protagonista de No mataràs. ¿Però qui fou realment aquest personatge amb certa aurèola mística entre els qui de la generació valenciana hui en dia més longeva encara resten vius? «Pepe el Carinyo era un dels millors en els anys trenta a la Safor. Estava pujant, però la guerra li va desbaratar la vida, l'esportiva també» (Labrado 2015: 9). Carinyo fou un destacat jugador -ara en diríem mediàtic- de pilota, «un esport aspre i delicat alhora» (2015: 10), a qui amb l'esclat de la Guerra Civil, i després d'una partida tràgica, el joc s'acabaria per a ell. En canvi, la seua llegenda es va anar fent més i més gran. Acusat imprecisament de líder dels maquis, sobrevivint d'amagat, jugant al gat i la rata amb la Guàrdia Civil, «aquell home valent $\mathrm{i}$ bo es va convertir en un heroi popular, en l'últim bandoler i roder valencià, en el bon sentit de la paraula». ${ }^{2}$ Com apunta el director literari de Bromera, Gonçal López-Pampló,

\begin{abstract}
Labrado recupera el mite d'un personatge admirat pel poble. I ho fa partint de la documentació disponible, sense pràcticament concessions a la ficció. Fet i fet, som davant de la reconstrucció de la història d'aquell home -alt, prim i ben tallat- que el pas dels anys ha anat silenciant. Amenaçat per l'esquerra primer i perseguit per la dreta després, Pepe el Carinyo és potser el símbol d'un món que s'acaba i de la partida que tants valencians van perdre ofegats entre dos bàndols (López-Pampló 2015).
\end{abstract}

La polifonia d'opinions compilades per Labrado -modelades i orquestrades destrament, com tot gran dominador de l'ofici d'escriure- atorga als llibres un to com de veu coral que incrementa la sensació d'objectivitat, atés el contrast de les explicacions, la divergència dels punts de vista i la dissensió d'ideals polítics de les persones i fonts consultades. Labrado traça els fils argumentals aglutinant informació dispersa, sovint amb versions antagònicament contraposades d'uns mateixos fets, perquè siga el lector qui construïsca, per ell mateix, una opinió pròpia sobre uns successos reconstruïts justament gràcies a aquest prisma ampli i diversificat. Ara bé, ¿els fets narrats - denunciats, més aïna: contats de forma distinta a les versions oficials per veu de tants testimonis reals amb el propòsit últim de rescabalar-los de l'oblit i fer-ne justícia literària- són per si mateixos indicis suficients perquè tots tres llibres puguen considerar-se novel la històrica? N'hi ha prou, amb això? Reprenguem Simbor:

2 https://apuntmedia.es/va/a-la-carta/programes/vist-en-tv/plaerdemavida/17-11-2018-victor-labrado-el-paper-de-les-biblioteques 


\begin{abstract}
Des de la nostra perspectiva actual, però, no podem seguir acceptant sense reserves la definició tradicional, que concebia la novel la històrica com la barreja de ficció i d'història. No, la novel la històrica, si és novel la, ha de ser necessàriament ficció. Això sí: una ficció amb uns lligams molt peculiars amb el món factual. (...) La novel la històrica, per tant, serà més justament entesa si oblidem la definició tradicional, basada en el grau d'allunyament o aproximació a la realitat (...). La juntura, proposada tradicionalment, de realitat i d'imaginació esdevé inoperant. L'activitat de l'historiador es basa en la invenció (inventa hipòtesis que ens ajuden a entendre el passat); el treball del novel lista es basa en la ficcionalització (ficcionalitza el passat). El tret clau diferenciador deixa de ser la comparació entre el grau d'objectivitat, d'ajustament a la veritat en la visió del fragment del període històric recreat, substituït per l'anàlisi de la transformació d'un tipus d'enunciat en un altre: la dicció ficcional de la història en el cas del novel lista (Simbor 1997: 109-110).
\end{abstract}

Basant-nos en tals consideracions, els llibres guerracivilistes de Víctor Labrado són, fet i fet, obres de difícil encaix. Si més no, pel que fa als fets històrics dels assassinats atribuits per la historiografia oficial als personatges protagonistes de La guerra de quatre i No mataràs. Tanmateix, la història oficial no té per què ser sinònim de veracitat o certesa empírica d'uns episodis passats i jurídicament prescrits (Oleza 1996).

\begin{abstract}
El novel lista il'historiador comparteixen els mateixos materials (esdeveniments i personatges de períodes passats), però l'objectiu i les regles del treball són diferents. L'objectiu de l'historiador és la descripció i explicació objectiva dels fets, per tant ha de partir sense cap intenció o voluntat personal. L'objectivitat és la seua categoria sacrosanta. Al contrari, el novel lista, en general, a desgrat de les proclames d'objectivitat de la línia realista, i excepcions a banda, parteix d'un objectiu o voluntat personals, de tal manera que l'elecció dels esdeveniments respon a un criteri intencional i premeditat (Simbor 1997: 111).
\end{abstract}

Simbor, però, prenent com a base Lukács (1976) i Eco (1992), reconeix que davant d'una versió pretesament objectiva d'un historiador, el novel lista opta pel discurs de l'autenticitat, atés que l’objectiu últim és sempre intentar influir sobre el lector. De fet, segons Fernández-Prieto (1998) l'objectivitat i la veracitat dels fets descrits per l'historiador no està exempta de suspicàcies alineades al corrent ideològic amb què aquest s'hi puga identificar i posicionar. D'acord amb els postulats gennettians (1982), «la novel la històrica es pot entendre, per tant, com el resultat de la transformació de les fonts documentals en un hipertext novel lístic» (Simbor 1997: 113), el qual presentarà sovint una visió crítica $\mathrm{i}$ alternativa a les fonts i informacions oficials, «cas de les novel les històriques aparegudes en el postfranquisme, on es presentava una visió del nostre passat molt diferent al difós per la historiografia oficial» (1997: 113). Comptat i debatut, ¿quina és la fórmula màgica de la novel la històrica a l'ús o prototípica? La crítica especialitzada postula que haurem de basar-nos sempre, d'entrada i com a condició sine qua non, en la llunyania temporal: en aquest sentit, l'intent de Labrado de recuperar la memòria històrica nostrada a través de veus de testimonis anònims i subalterns en aquesta sèrie de novel les guerracivilistes s'hi adscriu a la perfecció. 
Hi ha, però, un altre factor encara més important: la relació d'aquests personatges (persones físiques que van existir realment) amb l'entorn. Això és, com els fets històrics recreats per al relat van condicionar el devenir d'aquests hòmens i dones reals. Segons Àlex Broch (1991a i 1991b), el quid d'aquest subgènere novel lesc rau justament ací: «un dels elements més definidors i més fàcils de constatar en la novel la històrica és el personatge. Pot ésser un personatge fictici o real, però ha d'estar insert clarament en la història, en els fets històrics, aquests han de determinar la seva biografia» (Broch 1991a: 109). Pepe el Carinyo; Tomàs, Rafel i Carmen; Vicent Just Millet... persones reals i protagonistes respectius de No mataràs, La guerra de quatre i Quan anàvem a l'estraperlo, encarnen fil per randa la dicotomia «personatgesfets històrics», característica de l'estructura narrativa d'aquest tipus d'obres, en què «la història determina el relat» (1991a: 109). Els fets històrics viscuts -patits, soferts- pels protagonistes d'aquestes històries guerracivilistes rescabalades per Labrado determinaran, en conseqüència, la trama, el devenir argumental i l'estructura cronològica i seqüencial dels llibres en qüestió.

\subsection{El passat més recent}

Simbor, però, apunta, encara, un tercer element de necessària confluència per a la consideració i inclusió consegüent d'una obra literària dins d'aquest paradigma novel lístic: el temps. Assumint que els fets esdevinguts en una novel la històrica són efectivament i irrefutablement passat, ¿quina distància temporal caldrà que haja transcorregut des del present de l'escriptor perquè puguem considerar-la suficient $i$, acomplerta tal premissa, titllar d'històrica una determinada novel la?

\footnotetext{
Broch, per la seua banda, afirma que «la novel la històrica comporta un temps no viscut per l'autor». Serrahima i Boada també acaren aquest problema temporal en un sentit semblant al citat de Broch: una novel la històrica ha de «referir-se a fets que el seu autor no hagi viscut». És a dir, li caldrà fer un esforç de reconstrucció ajudat de l'estudi de diverses fonts: «fets i èpoques, properes o llunyanes, que no hagi pogut fer reviure sense un esforç de reconstrucció, més o menys complet, que li hagi exigit sortir-se dels límits de l'experiència personal i haver de recórrer als tractadistes, als documents o, si més no, als records dels supervivents» (Simbor 1997: 112-113).
}

Paradoxalment, aquesta afirmació de Serrahima i Boada (1996) que arreplega Simbor confirma la perfecta confluència d'astres per considerar novel la històrica les tres novel les de Labrado esmentades fins ara, ja que al fet que els episodis històrics determinen la trama del relat i condicionen per sempre més les vides d'uns personatges protagonistes ben reals -esguitant-los inclús de mort-, cal afegir que la Guerra Civil en si i la primera postguerra fou un període no viscut ni experimentat de primera mà per part de l'autor de Sueca. Ara bé, per aquesta mateixa regla de tres, el revelador assaig de Simbor, tot i deixar en l'aire alguns interrogants, permet existimar igualment com a històriques unes altres novel les de Labrado argumentalment més pròximes en el temps com Veus, la mar-inclús el bestseller La mestra-, si ens atenem als enraonaments que se'n desprenen: 


\begin{abstract}
Carlos Reis i Ana Cristina M. Lopes, per exemple, asseguren que la novel la històrica exigeix «la colocación de la diégesis en épocas históricas remotas» (1996: 184). Pel que sembla, ningú no dubta que, com més remot siga el passat del món diegètic, més fàcilment serà reconeguda com a històrica la novel la, mentre que, com més petita siga la distància entre el temps de la narració o acte narratiu i el temps de la història, menor serà la unanimitat de les opinions. La frontera temporal precisa resulta impossible de marcar: quan comença el temps no viscut per l'autor i per a conéixer el qual ha de recórrer a fonts orals o escrites de documentació, al segon anterior de la seua naixença, a l'any, als deu anys, als vint-i-cinc...? (Simbor 1997: 113).
\end{abstract}

Absència d'unanimitat de criteris. Mancança d'avinença o assentiment. La difusa frontera entre allò que es considera temps passat (Mendiola i Gallo 2000) en relació amb qualsevol episodi pretèrit (preferentment no viscut de primera mà per l'autor, sense que això siga però requisit), planteja el debat de poder considerar - per què no- relat històric fins i tot el primer gran èxit comercial de Víctor Labrado, La mestra (1995). Publicada inicialment per $3 i 4$ i reeditada a posteriori per Bromera en diverses col leccions, La mestra és, comptat i debatut, la història de Marifé Arroyo, una pedagoga precisament filla d'immigrants d'origen castellanoparlant que va encetar una lluita personal en favor de l'ensenyament en valencià i els drets lingüístics dels seus alumnes a cavall entre els anys setanta $\mathrm{i}$ vuitanta del segle passat. Aquesta crònica realista o novel la sense ficció narra -o millor dit, denuncia, vindica i posa en valor- la història i els fets dolorosos viscuts per la protagonista, represaliada i expulsada de l'escola del poble de Barx (la Safor) pel seu compromís en la defensa dels drets lingüístics. Víctor Labrado, que visqué aquest episodi de ben a prop en tant que docent i company de Marifé en aquell mateix centre educatiu, relata «l'experiència de qui s'ha convertit en el símbol d'una generació d'educadors compromesos amb la llengua i disposats a introduir i consolidar el valencià en l'àmbit educatiu des de les premisses de la renovació pedagògica» (Murgades 1995).

Al llarg del llibre no s'explicita en cap moment els estats d'ànims ni els girs psicològics experimentats per Marifé, la protagonista, davant l'esdevenidor dels fets inherents a les últimes cuetades del règim dictatorial. Simplement n'explica els episodis ocorreguts, a tall de crònica. És per tant el lector qui pren partit i assumeix, per ell mateix, la sensació d'angoixa davant de la injustícia i la persecució -orquestrada institucionalment- que pateix la mestra, una història que Labrado ha exhumat pretesament de l'oblit i la desmemòria d'un indret i un col lectiu concrets amb l'objectiu d'extrapolar-la i convertir-la en símbol d'un conflicte de valors endèmic, cronificat, repetit i reproduit al llarg i ample del País ja en aquell temps un tant llunyà per a gran part de la societat valenciana actual. No debades, La mestra segueix encapçalant a hores d'ara els rànquings de llibres més llegits a les facultats de magisteri valencianes i, fins i tot, ha esdevingut uns dels darrers bits de Zoo, el grup musical valencià més mediàtic del moment:

En eixe context, arriba una mestra, / rebel, decidida, valenta.

(...) Arriba l'expedient disciplinari, / volem que memoritzen l'oració i l'abecedari.

Horaris estrictes, i un pati ben delimitat.

(...) Vingueren l'alcalde, la guàrdia, inspectors / a defendre l'absurd, a donar-li lliçons.

(...) No van poder, mai no podran. 
(...) D'aquella mestra hui som alumnat avantatjat.

«La mestra», Zoo Posse (Raval, 2017).

Tot i que Labrado va viure amb ulls propis aquell capítol crucial en la història del poble de Barx, el fet cert és que el binomi (exigit per a la crítica) entre succés verídic i personatge real condicionat -marcat- per aquest succés es consuma en tota la seua dimensió, ja que els fets determinen de més a més la trama de la novel la. De fet, Simbor reconeix que l'etiqueta de novel la històrica és realment atribuïble, per damunt de la resta d'arguments exposats al seu assaig i reproduïts ulteriorment en aquest article, quan un escriptor busca aclarir la veritat d'uns fets pretèrits $i$ traure'n l'aigua clara. Més encara: per determinar si som davant o no d'una novel la històrica, el llibre en qüestió presentarà

\begin{abstract}
un discurs regit no sols per l'eficàcia sinó també per la veritat, si més no la veritat del novel lista, contra les deformacions de certa historiografia, car no podem oblidar que allò que hom anomena la veritat històrica és una construcció cultural a partir dels fets donats com a certs i que, com a tal, admet discrepàncies no sols d'època a època sinó fins i tot a l'interior d'una mateixa època (Simbor 1997: 111).
\end{abstract}

Aquesta consideració final encaixa com l'anell al dit a les novel les guerracivilistes de Labrado revisades adés, però seria també perfectament aplicable - de fet, potser més encara- en el cas de La mestra. I fora igualment vàlida, a l'ensems, per a la seua publicació més recent, Veus, la mar (2018), guardonada amb el prestigiós premi Joanot Martorell de Novel la 2018. Manel Alonso (2019) considera Veus, la mar com «una obra de no ficció on el narrador es disfressa de documentalista i va recollint i col leccionant els records dels vells mariners dels ports del sud valencià (...) Veus a punt d'extingir-se que feren de la mar la seua vida». A ulls d'aquest autor i crític valencià,

\footnotetext{
La memòria individual d'aquests llops marins és la de l'evolució de les arts de pesca i de les embarcacions, els moviments dels bancs de peixos, els interessos puntuals dels mercats, el creixement dels ports. Però també és el pas cruel de la història per les seues vides, la guerra civil espanyola amb els avions metrallant la població civil; la Segona Guerra Mundial, amb el moviment de vaixells i submarins, els enfrontaments i els naufragis que feren aparéixer entre les xarxes de pesca els cadàvers de molts militars. La guerra d'independència d'Algèria, la persecució de les llanxes algerianes, la retenció als ports, la corrupció d'alguns funcionaris. I l'aparició del turisme que va negar el litoral d'urbanitzacions i omplint la mar de deixalles. És, també, l'esforç, la lluita constant, la tenacitat, la intel ligència, l'astúcia, el valor, la sort i la desgràcia d'uns homes que van viure i que van morir alguns d'ells sobre les onades infinites de la mar (Alonso 2019.)
}

Paral lelament, Gerard E. Mur (2019) relata que «l'editora Pilar Beltran [d'Edicions 62, grup editorial responsable del tiratge de Veus, la mar] (...) encabeix el llibre dins la tradició més marina de la literatura catalana». Si bé el situa, per temàtica, al costat d'obres de referència com Aigua de mar de Josep Pla, El rem de trenta-quatre de Joaquim Ruyra o Catalunya des del mar de Carlos Barral, Beltran reconeix, no obstant això, que la darrera novel la de Labrado «és un llibre atípic dins del panorama literari actual». Mur (2019) hi resumeix amb agudesa estil, tècnica, trama i contingut: 


\title{
Dari Escandell. L'encaix de la narrativa sense ficció de Víctor Labrado en el paradigma de la novel la històrica valenciana
}

\begin{abstract}
Labrado ha parlat amb una quinzena de patrons. La seva és una «novel la sense ficció». Tot el que s'explica és real, són veus, testimonis, història viscudes; ara bé, Labrado hi passa l'agulla del relat. Hi ha relacions de causa-conseqüència. Ha estat una feina de quatre anys, molta conversa, viatges a bord (...) «Volia posar la mar a l'imaginari del lector d'una manera diferent», diu sobre les intencions (Mur 2019).
\end{abstract}

El mateix Labrado puntualitza que la major part dels valencians vivim a menys de quinze quilòmetres en línia recta de la mar Mediterrània: «La costa ha estat tradicionalment la nostra via principal de comunicació» (Labrado 2018). En canvi, lamenta que els valencians siguem deficitaris en tots els aspectes relacionats amb una mar cada dia més allunyada del nostre món i la nostra realitat. Amb tot, potser és Àlex Milian (2019) qui millor capta l'essència de l'última producció de l'escriptor suecà, al seu parer «una joia (...) polifònica, amb un valor literari extraordinari»:

Veus, la mar no és ben bé una novel la coral tot i que hi ha molts personatges i cap protagonista. No és un recull de testimonis, tot i que són antics pescadors -homes que foren «xiquets de barca»- els que hi parlen. I l'autor, Víctor Labrado, diu que és una novel la de no-ficció tot i que molts lectors la podran llegir com un recull de contes. Perquè veritablement cada història narrada és independent de la resta. (...) El títol de la novel la juga, sens dubte, amb el doble significat de veus. Per una banda, Labrado dona veu als últims homes que poden parlar de la pesca sense motor (...). Per una altra banda, l'autor mostra el que no veiem rere la mar en calma: els oficis de la pesca, la dura vida a la barca; la costa com a escenari de guerra; els bombardejos de l'aviació italiana; la marxa al Marroc i Andalusia per pescar; el contraban; el servei militar o les desenes de vaixells enfonsats a la costa de les Marines (Milian 2019.)

Després d'aquest recorregut general -apressat- pel realisme desproveït de ficció de Labrado, l'interrogant proferit per Simbor en el seu cèlebre assaig sobre novel la històrica queda més de manifest que mai en aquest llibre mariner en què l'autor suecà sublima l'essència tècnica de totes les seues obres escrites anteriorment:

Però ens quedem sense saber què fer amb els relats múltiples juxtaposats, o siga situats tots al mateix nivell diegètic i, per tant, sense cap acte narratiu marc superior i global. Les dificultats teòriques son de gros calibre. (...) Alguns dels novel listes nord-americans d'entreguerres, com ara Dos Passos o William Faulkner, porten al màxim refinament aquesta estructura novel lística constituïda per un seguit de relats i textos diversos juxtaposats, sense cap acte narratiu marc que els puga regir (...) mostrant la realitat en la seua totalitat i complexitat mitjançant aquesta mena de tècnica calidoscòpica (Simbor 1997: 118-119).

Així doncs, haurà de ser de nou el lector qui deduïsca i extraga per si mateix la seua interpretació personal d'aquests mosaics polièdrics. No debades, quan una novel la com ara qualsevol llibre de Labrado es construeix a partir d'un model estructural polifònic, amb capítols o parts de gran autonomia i extensió variable, la visió de conjunt i l'assimilació consegüent del missatge final -agitador de consciències, per regla general- recaurà necessàriament i exclusivament en el lector. 
Dari Escandell. L’encaix de la narrativa sense ficció de Víctor Labrado en el paradigma de la novel la històrica valenciana

\section{Conclusions}

Labrado ha estat considerat sovint un outsider de les lletres catalanes contemporànies. Ben mirat, el cas és que ben pocs han sabut bastir com ell una trajectòria novel lística tan sòlida fonamentada en essència només a través d'un subgènere gens usual com la crònica realista o no-ficcional, si més no en l'àmbit literari nostrat més immediat. Cartenguts o no al seu torn novel la històrica, el que sembla indiscutible és que tots i cadascun dels seus llibres s'encabeixen a la perfecció com a «novel la de compromís nacional, de compromís social, de compromís ideològic, és a dir, (...) novel la plantejada com a vehicle per al nosce te ipsum» (Simbor 1997: 114) dels valencians com a col lectivitat. Els personatges de tota condició a qui Labrado hi dona veu -directament, o bé per boca dels qui parlen d'ells des del record- testimonien com ningú, mitjançant pinzellades d'una perticularitat prodigiosament universal, el que ha estat $-\mathrm{i}$ el que ha hagut de patir i resistir- la societat valenciana al llarg del segle passat.

Labrado s'allunya potser dels cànons o estàndards en novel la històrica en català (Torroella 2011; Tiñena 2016). Això és una evidència. Tanmateix, aquesta genuïnitat idiosincràtica l'ha fet mereixedor -juntament amb un savoir faire exquisit i un ofici d'escriptor impecable quant a tècnica, prosa $\mathrm{i}$ eficàcia comunicativa- de nombrosos reconeixements: en forma de lectors (hi hem advertit, com a símptoma inequívoc, com els seus drets d'autoria són cobejats per la indústria editorial) i reputats guardons. Si Gustau Muñoz (2014) ressaltava que darrerament la novel la històrica gairebé «s'endú tots els premis literaris més importants i ben dotats que s'atorguen al País», Labrado és sens dubte, des de la particularitat de la no-ficció novel lada, un dels exponents més destacats i destacables. 
Dari Escandell. L'encaix de la narrativa sense ficció de Víctor Labrado en el paradigma de la novel la històrica valenciana

\section{Bibliografia}

Alonso, M. (2019) «Veus, la mar», Diari Gran del Sobiranisme, 15/10/2019. Recuperat de: https:// diarigran.cat/2019/10/15/veus-la-mar/

Beltran, A. (2009) «La guerra de quatre», Blog del CAL, 27/12/2009. Recuperat de: http:/ /blogdelcal. blogspot.com/2009/12/la-guerra-de-quatre.html

Broch, À. (1991a) La literatura catalana dels anys vuitanta, Barcelona, Ed. 62.

—_. (1991b) «La novel la històrica del postfranquisme», L'Avenç, 56, pp. 64-69.

Eco, U. (1992) «Postil la», dins Eco, U. El nom de la rosa, Barcelona, Destino.

Escolano, J. M. (2013) «Ressenya de Les trobades. 25 anys d'Escola Valenciana, de Víctor Labrado», Ítaca. Revista de Filologia, 4, pp. 251-256.

Fernández-Prieto, C. (1998) Historia y novela. Poética de la novela histórica, Pamplona, Ediciones Universidad de Navarra.

Gennette, G. (1982) Palimpsestes, París, Seuil.

Guillaumes, T. (2004) «L'Edat Moderna a la novel la històrica en llengua catalana: anàlisi del fons històric i del marc de producció», Manuscrits, 22, pp. 169-171.

Mendiola-Mejía, C. / Gallo-Fernández, C. (2000) «De veras o de novela: Un ensayo en la distinción novela histórica e historiografía», Historia y grafía, 15, pp. 97-117.

Milian, À. (2019) «El miracle de les paraules i els peixos», El Temps, 1818, 15/04/2019. Recuperat de: https://www.eltemps.cat/article/6883/el-miracle-de-les-paraules-i-els-peixos

Muñoz, G. (2014) «El triomf de la novel la històrica», País Valencià, Segle XXI, 23/11/2014. Recuperat de: https://paisvalenciaseglexxi.com/2014/11/23/el-triomf-de-la-novel la-historica/

Mur, G. (2019) «Víctor Labrado. La mar està morta», Núvol. El digital de cultura, 10/01/2019. Recuperat de: https://www.nuvol.com/noticies/victor-labrado-la-mar-esta-morta/

Murgades, J. (1995) «La mestra», Els Marges: revista de llengua i literatura, 53, p. 117.

Labrado, V. (2002) La guerra de quatre, Alzira, Bromera.

—. (2010 [1a ed. 1995]) La mestra, Alzira, Bromera.

—. (2015) No mataràs, Alzira, Bromera.

—_. (2017 [1a ed. 2004]) Quan anàvem a l'estraperlo, Algemesí, Andana.

- (2018) Veus, la mar, Barcelona, Ed. 62.

López-Pampló, G. (2015) «Sinopsi», dins Labrado, V. No mataràs, Alzira, Bromera.

Lukács, G. (1976) La novela histórica, Barcelona, Grijalbo. 
Dari Escandell. L'encaix de la narrativa sense ficció de Víctor Labrado en el paradigma de la novel la històrica valenciana

Oleza, J. (1996) «Una nueva alianza entre historia y novela. Historia y ficción en el pensamiento literario del fin de siglo», dins Romera Castillo, J. (ed.) La novela histórica a finales del siglo XX, Madrid, Visor, pp. 81-96.

Peris, R. (2017) «Sinopsi», dins Labrado, V. Quan anàvem a l'estraperlo, Algemesí, Andana.

Preston, P. (2010) L'bolocaust espanyol. Odi i extermini durant la Guerra Civil i després, Barcelona, Base.

Salvador, V. (1986) «Estudi introductori», dins Lozano, J. Crim de Germania, València, 3i4, pp. 9-69.

Serrahima, M. / Boada, M. T. (1996) La novel ta històrica en la literatura catalana, Barcelona, Publicacions de l'Abadia de Montserrat.

Simbor, V. (1997) «Sobre la novel la històrica actual», Caplletra, 22, pp. 105-128.

Tiñena, J. (2016) «La novel la històrica a Catalunya», Catalan Historical Review, 9, pp. 181-196.

Torroella, J. (2011) «La novel la històrica en la narrativa catalana més recent», Serra d'Or, 616, pp. 102-105. 